Garcés-Galdeano, L. and García-Olaverri, C. (2020), "How important is family involvement for small companies' growth?", Journal of Small Business and Enterprise Development, Vol. 27 No. 4, pp. 531-554. https://doi.org/10.1108/JSBED-06-2019-0190

\title{
How Important is Family Involvement for Small Companies' Growth?
}

Lucía Garcés-Galdeano; Carmen García-Olaverri

Universidad Pública de Navarra

\section{Abstract}

We draw upon the socioemotional wealth perspective and agency theory to investigate how family involvement in management influences firm growth. Using a sample of 1,397 Spanish, small, high-tech firms, we classify three different types of firms: family firms managed by family-CEOs, family firms managed by non-family CEOs, and non-family firms. Consistent with our expectations, we show that firms managed by family-CEOs have less firm growth in comparison with the other two groups. When the family firm is managed by non-family CEOs, the presence of another family member in the Top Management Team (TMT) has a negative impact on firm growth. Finally, we found that founder-led family firms have better firm growth than descendant-led family firms. Consequently, our research contributes to a deeper understanding of the relationship between family management and growth.

\section{Introduction}

There is a long debate about the relationship between family ownership and firm growth (Saridakis, et al. 2018). Some authors support a positive effect of family ownership on growth, because the owners of family businesses act to ensure the continuity or longevity of the enterprise (Miller et al., 2008). Other scholars portray a more negative picture of family businesses, arguing that their difficulties in growth and survival are attributed to 
resource restrictions (Grassby, 2000), conservative strategies (Allio, 2004), and family conflicts such as succession difficulties (Schulze et al., 2003).

However, although there are many research studies about differences between family and non-family businesses in terms of growth, existing literature has overlooked the diversity of family firms and their heterogeneous behaviours. Most studies tend to study family firms as a homogenous form of organization, and several scholars have recently called for more nuanced insights about the drivers of heterogeneity among family firms (Chrisman \& Patel, 2012; Gómez-Mejía et al., 2013). In particular, one of the reasons why family firms are different is family involvement in management positions (Pittino et al. 2019; Hambrick, 2007; Hambrick \& Mason, 1984). Particularly, the management of the company may have a greater or lesser amount of family participation. That is, family firms, on one hand, could be led by a family CEO or a non-family CEO, and on the other hand, the top management team could be composed of family as well as non-family managers (Klein, Astrachan \& Smyrnios, 2005).

The purpose of the present study is twofold. Firstly, differences between family and nonfamily firms are analysed in terms of growth. We examine the crucial role of family ownership and leadership by considering the more nuanced effects of CEO identity (family or non-family) (Miller, Minichilli \& Corbetta, 2013). Based on this, we classify three types of firms: family firms managed by family-CEOs, family firms managed by non-family CEOs, and non-family firms. Building on prior research, we conceive different kinds of family firms in terms of their emphasis on current family control and the importance they place on non-economic or socioemotional goals in their decisionmaking.

Secondly, we study in depth the heterogeneity of family businesses and try to close the gap by exploring the effect of family involvement on small firm growth. One of the most 
important sources of heterogeneity lies in the fact that family members occupy upper echelon positions (Hambrick \& Mason, 1984). We integrate the socioemotional wealth perspective (SEW) and the agency theory into a coherent model to develop consistent theoretical explanations on how family involvement in management, and its combination with the Top Management Team (TMT) and the generational stage of the firm, affect business growth. They help us provide a more complete picture of the reasons why family control of a firm will be beneficial or harmful for family firms. Specifically, we explore how the extent the level of family involvement in management (Chirico and Bau, 2014) influences firm growth. From the agency perspective, it is known that family firms have lower agency costs. However, this effect may be offset by the costs of family management. Family managers are not recruited from the general market of managers, so they are usually less trained than professional managers, and this leads to worse firm outcomes. From the SEW perspective, we also study how family involvement weighs differently the balance between the economic and non-economic goals giving place to the mixed gamble approach (Gómez-Mejía et al., 2014a). Thus, we suggest that family firms differently balance the value of business growth's benefits and costs depending on the degree of family involvement (Bauweraerts et al. 2019; Alessandri et al., 2018). This induces either positive or negative consequences for firm growth. In this sense, we analyse the possible influence of two factors on the growth of a company. Both factors modulate family involvement on the firm. They are more likely to affect the family's preferences for SEW or financial wealth (Sciascia et al., 2014), and as a consequence, they could have different influences on firm growth. The first one is the presence of family members in the TMT. The second one is the generational stage of the firm, that is, if the CEO is the founder of the firm or is any descendant. 
Given the heterogeneity and diversity of family businesses, we have chosen a very specific sample where we can study the differences in leadership within a homogeneous group of family businesses. We test our hypothesis used a sample of 1,397 small firms operating in high- and medium-high technology sectors. The companies in the high-tech sector constitute a differentiated group with respect to other industrial sectors, presenting a specific growth profile. However, if we deepen the analysis within that group and in that same stratum of size (less than 50 employees), we still observe notable differences that we believe can be explained, in part, by issues related to ownership and the presence of family members in positions of management responsibility. Consistent with our theoretical arguments, our findings suggest that the presence of non-family CEOs in family firms results in a significant increase in a firm's growth. However, non-family CEO's do not always outperform. When these non-family CEOs are in the presence of a family TMT, there is a negative influence on firm growth. Finally, founder-led family firms will show higher firm growth than descendant-led family firms.

Thus, our contributions to the existing literature are both theoretical and empirical. Theoretically, we add additional insights about the drivers of heterogeneity among small family firms on firm growth, addressing recent calls for more nuanced views of how socioemotional wealth and agency theory considerations drive strategic behaviour in family firms (Chrisman et al., 2015; Chua, Chrisman \& De Massis, 2015). Exploring differences among family firms regarding leadership, management, and generational involvement, our paper also responds to unceasing calls to study behavioural differences within family firms (Chua et al. 2012). Empirically, by incorporating considerations of different types of family firms, we reconcile contradictory findings regarding the level family involvement in family firms (in particular, family membership of the CEO), the 
top management team, and the generational stage - underlying different advantages and disadvantages in family firms' growth. Lastly, our research context offers a unique opportunity to expand existing research in small Spanish family businesses. We contribute to the debate on the difficulties of the Spanish economy, focusing on the role of family management in explaining low firm growth. In addition, most previous research has been conducted on large listed firms and has not addressed small firms, whose context may be particularly different in terms of growth.

The paper is organized as follows: In the next section, we discuss the implications of the family involvement on the firm and develop testable hypotheses. Section three describes in detail the sample and the measurement of variables. Section four provides the results of the empirical analyses conducted to tests the hypotheses. The final section discusses the results and summarizes our findings.

\section{Theoretical framework}

Enterprise growth has been studied by researchers for many years (Gupta, Guha \& Krishnaswami, 2013); it is especially important in small enterprises. In fact, the survival of small firms essentially depends on their ability to coexist with other relatively bigger competitors. The entrepreneurship approach is one which has analysed the growth phenomenon of small businesses. The main motivation is that most of these small companies are not able to expand during their life span (Davidsson et al., 2010), and they are not even able to grow (Doern, 2009). Authors such as Brush, Ceru, and Blackburn (2009) have shown that some firms do not have any intention to grow and others want to grow slowly, but at the same time, they try to be as profitable as big firms. This phenomenon of the growth of small firms is very complex and further research is needed 
in order to see how growth decisions are affected by the context and by the role of entrepreneur (Wright \& Stigliani, 2012). Regarding family firms, there are controversial findings about the relationships between family ownership and firm growth, especially in small businesses (Hamelin, 2013, Nordqvist et al., 2008).

One of the facts that characterize the Spanish business structure is the high presence of small and medium enterprises (SME). This is the reason why the Spanish context is particularly suitable for the study of small firms. More than $99 \%$ of companies belong to this stratum that accounts for $74 \%$ of employment. Concern about the low survival of this type of company and the difficulties for growth of those that survive are on the agenda of public decision-makers. Forty percent of Spanish SMEs do not survive the first three years of their existence. This figure is particularly worrying and it rises to $60 \%$ if we refer to small companies or to $75 \%$ if we refer to micro-enterprises. According to data from the OECD, Spain is the country with the second lowest survival rate of its SMEs. Only a small group of SMEs can be considered High Growth Firms in the sense of having grown well above the average of their industrial sector in the last three years. In addition, the presence of family businesses in the small business segment in Spain is so large that it is not possible to talk about small businesses without mentioning that the vast majority are family businesses. According to the latest report of the Family Business Institute (2015), family businesses represent $88.8 \%$ of the companies in Spain. This data varies according to the size and industrial sector of the companies. Within the microenterprises, family businesses represent more than $90 \%$ of the businesses. However, above this size, the family business represents $79.5 \%$ of the businesses. Thus, most SMEs are family businesses, and a large majority of family companies are SMEs. This is why addressing small business growth is particularly relevant in the family business context. 
In this paper, we use two different perspectives: agency theory and the SEW approach. Both reveal evidence for and against the benefits of family involvement. Taking into account the differences between owner-management and non-owner management, agency theory would predict a positive effect on firm value, because owner-management aligns the interests of owners and managers (Jensen and Mechling, 1976). Nevertheless, this effect could be negative if we consider the costs of family management. Family managers are usually not recruited from the general market for managers. They are part of the family, and they are not always properly trained to lead the business. This situation generally leads to quality differences between family managers and professional managers, and this may reduce a firm's performance. In addition, family-managed firms tend to be characterized by carefulness in strategic decision-making, because of the fear of losing family control. This risk aversion makes family managers avoid adopting new management principles, because they consider them to be too risky.

The socioemotional wealth approach (SEW) is another informative perspective to view the advantages and disadvantages of a family business. On one hand, there is a positive view regarding family ownership's effect on growth, because family managers are very interested in the survival of the company (Miller et al., 2008) and have special features that make them unique (Stenholm, Pukkinen \& Heinonen, 2016). On the other hand, there is a more negative view of the family business in which the difficulties come to prevail. In fact, family firms may have the capacity to grow but are unwilling to do so, because they are aware of the possible negative consequences for family control over the firm (De Massis et al. 2014; Casillas, Moreno \& Barbero, 2010). The causes of this stagnation may be limited resources (Grassby, 2000), risk avoidance strategies (Allio, 2004), and internal family conflicts (Schulze et al., 2003). 
Previous scholars report that family enterprises have special incentives to intentionally limit growth, even if they have the financial resources that are needed. The reason is that, for family owners, the business is more than a simple source of income. They also care about family employment, pride, and identity (Zellweger et al., 2013). The SEW collects all non-economic elements related to family participation in the company (for example, family control and influence, identification of family members with the company, binding social bonds, emotional attachment, renewal of family ties with the company through dynastic succession). Under this approach, avoiding the loss of SEW is the principal objective for family owners (Gomez-Mejia et al., 2007). So, the concern for noneconomic factors will be greater for them, and they will always prioritize the protection of their socioemotional endowment (Garcés-Galdeano et al., 2016; Mahto et al., 2010). There is previous research that shows the distinct behaviour of CEOs' strategic decisionmaking in family firms compared to non-family firms (Garcés-Galdeano et al., 2017; Gomez-Mejía et al., 2007). For instance, Barth et al., (2005) examined the effect of owner-management on productivity in Norwegian small enterprises. They found significant differences in productivity. These differences could be explained by the management regime. Family firms run by professional managers were as productive as non-family-owned business, whereas those managed by owner managers were significantly less productive.

Therefore, based on the previous literature, we would expect, in general terms, that family ownership decreases firm growth. They might favour risk-avoidance decisions in favour of firm survival, and such decisions can be harmful to firm growth (Gomez-Mejia et al., 2007; Tsai et al., 2009). 
However, all of these findings about growth in small family firms should be rethought and revised when we refer to the context of companies in the high and medium-high technology sectors. In this specific context, there is extraordinary competition, and many companies do not consider the dilemma between slow or accelerated growth because the only way to survive is to grow as much as possible. In the high-tech sectors, growth is the unequivocal sign that technology is suited to the needs and expectations of customers whether they are final consumers or other companies. Although the competition is intense, these companies often operate in immature markets where there are many opportunities for growth such as great innovations in products and processes, new markets, and new needs for customers. For this reason, we wonder whether there are differences in growth between family and non-family businesses in this context of small technology-based companies or whether the presence of family members in management positions affects firm performance.

\section{The role of the CEO membership}

Although academic literature has generally treated family businesses as a whole, academics have recently started to acknowledge that not all family firms may place the same emphasis on SEW (Chua et al., 2015; Cruz et al., 2014; Miller \& Le Breton-Miller, 2014). For instance, Miller and Le Breton-Miller (2014) argue that there are two types of SEW priorities: restricted and extended. They postulate that restricted SEW is focused on family priorities and could run counter to the firm and the interests of non-family stakeholders. On the contrary, extended SEW would be focused on the long run and on the family, the business, and on all its stakeholders at the same time. Thereby, it is 
necessary to distinguish situations that can lead to higher or lower SEW. In other words, the relevance of SEW dimensions may change across different types of family firms. A recent framework based on SEW has integrated the mixed gamble concept and suggests that family firms make decisions as a mixed gamble by assessing possible gain and loss outcomes (Bauweraerts, et al. 2019; Bromiley, 2009). In this sense, most decisions would imply a difficult trade-off for family decision-makers (Kotlar et al., 2018) who typically balance possible gains and losses in terms of economic and SEW goals (Alessandri et al., 2018).

From the academic field, it has been established that one of the most important sources of heterogeneity lies in the fact that family members occupy upper echelon positions (Hambrick \& Mason, 1984). In particular, family firms can be managed by a family CEO or a non-family CEO.

Prior empirical studies suggest that family owners' emphasis on SEW is amplified when family owners appoint the CEO and other top executives based on personal relationships, thereby forming agreements by reason of kinship and not for full competition (Cannella et al., 2014; Cruz et al., 2010; Gómez-Mejía et al., 2001) and decision-making authority (Bertrand \& Schoar, 2006; Carney, 2005). Therefore, we expect the influence of family ownership through family owners' emphasis on family control and influence to become stronger when the CEO is a family member. Concentration of power provides a family CEO with particularly strong bargaining power (Connelly et al., 2010; Hambrick \& Mason, 1984). Family CEOs are often closely and intimately associated with their businesses for a long time. Thus, family CEOs would be more willing to take care of these non-economic goals. 
However, CEOs not related to the family will have little motivation to avoid losses of the SEW of the company. Instead, they will be more motivated to improve the company's performance and look for growth opportunities. This occurs because these goals are related to the CEO's personal objectives such as reputation, promotion, and remuneration (Garcés-Galdeano and García-Olaverri, 2019). The need to attract external professional talent for family firms' survival and growth is so important that it is key to know what the differences between family and non-family CEOs are and how these differences affect CEOs' strategy (Hauswald et al., 2015).

Non-family CEOs working in family firms have, in general, a different vision of the company from those of family CEOs. The latter have among their objectives maintaining the values and the role of the family in the company. While non-family CEOs have economic goals linked to growth or better performance, family CEOs are more likely to address the goals of preserving family values over economic goals (Berrone et al., 2010). This does not mean that family managers do not pursue good results, it simply means that their priorities are different. If the vision, objectives, and priorities are different, so are the management decisions. For instance, as Wennberg et al. (2011) pointed out, when the main objective of the family owners is to transmit the business to the next generation, long-term stability will be a priority and decisions that put the future of the company at risk will be avoided. In this situation, non-economic objectives guide the decisions of managers and lead them to develop a management style that is focused on stability and survival rather than growth. This way of managing, in which the survival goal prevails over the growth goal, is present in the values of many managers of small companies (Wiklund et al., 2003). 
These arguments are in accordance with the negative effects of agency theory in family firms, in which family managers are taken from a much more restricted pool of talent. According to Coleman (1990) and Burkart et al. (2002), this situation generally leads to a lower quality among family CEOs and may be detrimental to the productivity of the firms.

Based on the aforementioned arguments and seeing that within a family business there may also be differences depending on whether the CEO is family member or not, we will distinguish three types of companies. On one hand there are family businesses with a family CEO, and on the other hand there are family businesses with a non-family CEO, and finally there are companies managed by non-family members. We anticipate that while both family and non-family CEOs in family firms look for socioemotional wealth creation, non-family CEOs will give greater weight to firm growth than family CEOs. Thus, in terms of growth, we believe that family businesses with non-family CEOs are more similar to non-family companies. Therefore, we hypothesize that small family firms managed by family CEOs would be firms with less firm growth.

H1. Family firms managed by family CEOs show a negative influence on firm growth compared to the other two groups.

\section{The relationship between a non-family CEO and TMT composition}

As we previously hypothesized, family CEOs could have an adverse effect on performance in family firms (Pérez-Gonzáles, 2006). However, non-family CEOs may be more reticent than family CEOs to desire using firm resources to preserve the socioemotional endowment of the owning families (Gomez-Mejia et al., 2007, 2011). 
They are more apt to focus on economic performance than socioemotional wealth and less likely to be emotionally influenced by family issues. In addition, non-family CEOs have more expertise (Bennedsen et al., 2007) and bring more objectivity to the decisionmaking process (Huybrechts et al., 2013). Therefore, they make changes imposed by the complicated context in which they are struggling (Gomez-Mejia et al., 2013). In other words, non-family CEOs may promote company growth both by contributing with more expertise and by diminishing the potential negative effect of family socioemotional wealth and agency costs (Miller et al., 2013; Daily \& Dollinger, 1992).

Notwithstanding the first hypothesis, there is some indication in the literature which suggests that the benefits of employing nonfamily CEOs is contingent on context. Villalonga and Amit (2006) show a combination between a nonfamily CEO and a family chairperson of the board optimizes firm performance. Miller et al. (2014), however, find that firms with family and non-family co-CEOs tend to underperform when compared with firms with only a non-family CEO. Moreover, Sciascia and Mazzola (2008) demonstrate that a non-family CEO leads to improved firm performance despite possible goal misalignment. Therefore, several notable studies add nuance to these findings and indicate that a proper balance of family and non-family members improves firm performance.

Our suggestion is that non-family CEO effectiveness will be moderated by the composition of the TMT. Particularly, this will depend on whether there are family members in the TMT.

The power of top managers plays a key role in strategic decision-making (Finkelstein, 1992). In particular, they highlight the importance of family affiliation as an antecedent 
to power in top management teams. Family TMTs frequently act as a "unique agent in which both ownership and management are concentrated, determining a personalization of authority that gives family members extremely high power and legitimacy within the organization" (De Massis, Frattini, Pizzurno, \& Cassia, 2015a, p.4). This high level of family control means that the company prioritizes its own non-economic interests. Without formalized management practices or bureaucratic constraints, family TMTs could head interesting projects that would improve future growth. In addition, the family TMTs have more close connections within the family business. They know their clients and the market even before their employment in the family business; so, they have profound in-depth knowledge (Kellermanns \& Eddleston, 2007).

However, this discretion and power would be different depending on the CEO and whether he or she is a family or non-family member of the firm. On one hand, in addition to a family CEO, a family TMT may better grasp the family's goals and perspectives. Generally, appointing a family member to the top management team promotes more family members to participate in family governance, providing different points of view and representing more non-economic interests. In this scenario, firm management is more strongly driven toward the attainment of SEW goals.

On the other hand, the relationship of a non-family CEO with the firm is often more utilitarian (Lubatkin, Schulze, Ling, \& Dino, 2005) and conflicts of interests with the TMT in relation to business expansion could be a problem. According to Miller and Rice (1988), non-family CEOs could go in search of growth objectives, but family top managers could cause relationship conflicts. In these types of situations, agency problems arise because of the different preferences between the CEO and the top management team. The list of possible conflicts is long: discrepancies over the control of the company and 
the position occupied by family members, differences in business goals (e.g., international expansion), and different priorities on financial aspects. Growth may lead to problems among members of the family and among members of the management team, depending on their belonging or not belonging to the family. All this can affect the survival of the firm (Kellermanns \& Eddleston, 2007, 2004; Jehn, 1997). In the long term, this conflicting relationship between growth and survival can lead the family owner to slow down growth goals.

Therefore, non-family CEOs may not always outperform. A non-family CEO may be forced to share power with the family members on the TMT, and the CEO's discretion to act in the best interest of the company is likely to be restricted. This non-family CEO must now take into account the priorities of other family executives. That is, he or she must meet the SEW objectives, because they preserve the preferences of the family members in the TMT. Families that hire an external CEO but keep some family member in the TMT are suggesting that they will not give up the SEW perspective. They do not want to lose their control and their legacy. They need to grow, but they do not renounce socioemotional wealth goals.

Moreover, the unity of the company could enter into crisis when the agency problem arises; that is, when the non-family CEO has to share power with other family members due to conflicts between family-centric and business agendas.

Based on these arguments, we propose that in small, high, and medium-high tech firms: H2. In family firms, those managed by non-family CEOs with a family TMT will show a negative influence on firm growth.

\section{Generational stage of family CEOs}


In recent years, the academic literature has addressed the impact of the generational stage on firm performance (Casillas et al., 2010; Cruz \& Norqvist, 2010) from different perspectives.

The agency perspective has been used to analyse managerial behaviour in the succession literature (Giambatista et al., 2005). Fama \& Jensen, (1983) already announced the fact that family businesses were less exposed to agency costs, but this does not mean that they do not exist. Agency problems do occur in family businesses, and they can increase when these firms develop over generations. Some authors pointed that many of these problems arise because of increasing family conflicts and dysfunctional altruistic behaviour when the next generation starts leading the company. A study of Schulze et al. (2003) showed that in a sibling partnership, the level of ownership dispersion is high, and this can result in a more risk averse behaviour and eventually lead to a reduction in firm growth. In first generation managed companies, authority is highly concentrated because the founder both owns and manages the firm, thus there is a moderate agency problem. When the family grows and different individuals united by ties of blood take responsibility, the authority is diluted (Cruz \& Nordqvist, 2012) and agency problems could become deeper. Compared to the second and subsequent generations, the founder of the company has more power and authority (Mitchell, Hatt, Valcea \& Towsend, 2009), and this power concentration of authority promotes a greater entrepreneurial orientation (Chrisman, Chua \& Steier, 2003) and growth.

Furthermore, when power is highly concentrated in the founder family, it is reasonable to expect less reliance on formalized management practices, as these would inhibit the family owners' freedom (Carney, 2005). Formalization is a form of control over the individual behaviours of managers and objectifies decision-making. Scholars have long 
recognized that formalization obstructs openness, which is needed to see new outside opportunities (e.g., Jansen et al., 2006). As family owners put greater emphasis on control, they are likely to relax formalization so that the efforts of key decision makers can be directed towards expanding aspects of the external environment, producing greater opportunities for growth.

From the SEW perspective, the generation that is leading the company may also have a different balance between economic and non-economic objectives. In the new generations, the objectives and interests can be very different. They can even come into conflicts (Ward, 1997) that affect their strategic decisions, including growth. For instance, Cannella et al. (2015) argue that lone-founder firms embrace an individualistic and entrepreneurial identity that focuses on innovation and economic opportunities and align with the traditional shareholder-wealth maximization goals.

In addition, delving deeper into the SEW perspective, the importance of the different dimensions of the SEW can change among family businesses. When we talk about the first generation, we refer to entrepreneurs who want to leave the company to their children in the best possible condition. Therefore, although their priority is to keep control of the company in their own hands, they also worry about improving the competitiveness of their companies. They are looking for new markets and trying to improve the efficiency of the company, so they are more open to risk. However, the objectives of the managers who have received the company from their relatives, may not seek much growth but survival. They could be more risk averse. They feel the responsibility to keep the company alive and to take care of the legacy that they received from previous generations. In this scenario, growth is not as important as SEW values, specifically survival. 
Thus, based on these arguments, we suggest that, in the context of small high and medium-high technology firms, growth would be higher in first generation-managed firms than in second and subsequent generation-managed firms.

H3: Founder-led family firms will have better firm growth than descendant-led family firms

Figure 1 shows the sequence followed by hypothesis.

\section{Methods}

\section{Sample collection}

The data used in this research is a representative sample of small Spanish firms belonging to high and medium-high technology companies in the service sector as well as in the manufacturing industry. To obtain the sample, we used the SABI database that provides relevant information on 1,570,000 Spanish companies.

Our focus was to create a sample of 1,500 small firms with less than 50 employees who develop their primary activity in high or medium-high technology sectors (manufacturing or service industries). For this purpose, we employed the classification of the OECD and the National Statistical Office (INE). ${ }^{1}$

1

See www.ine.es/daco/daco42/daco4217/lstsectcnae.xls for a list of high and mediumhigh technology industry sectors. 
The company in charge of carrying out the survey selected a sample of 10,565 firms with the characteristics mentioned. The sample selection process was made randomly and took into account the representativeness of the industrial sectors, the legal form of the firm, and size strata. With a confidence level of 95 percent, the sampling error was \pm 2.34 percent. The companies were chosen at random within each industry sector using computer-aided telephone interviewing software.

Interviews were conducted in 2010 by interviewers from a company specializing in surveys and market research. Interviewers received prior training on some relevant concepts of the survey. From the sample of 10,565 companies, more than 10,200 companies were contacted. Of these, 1,485 agreed to participate; so a 14.5 percent response rate was achieved. The $\mathrm{CEO}$ of the company was responsible for responding to the questionnaire. We interviewed the CEO because the CEO has the broadest perspective of the company (Cycyota, et.al, 2002). The interviews lasted approximately half an hour. Missing values reduced the sample to 1,397 firms. In terms of size, industrial sector, or legal form, there were no differences between firms that agreed to participate and those who refused.

In order to avoid problems of common method bias, different response formats for the measurement of the variables were applied (zero-to-ten scale, five-point Likert scale, seven-point Likert scale, dummy variables, etc.). Nonetheless, we conducted the Harman's Single Factor Test. The results indicate that there is no problem of common method bias (the shared variance of 0.21 is far from the 0.50 threshold). 
Being aware of the importance of some aspects such as size, industrial sector or intensity of competition on growth, we sought to limit variability by focusing on a more homogeneous group of companies: companies of a similar size with the same technological complexity and with the same geographical origin.

The main reason why we choose this small firm sample is that there is a widespread concern about the low survival of this type of company and the difficulties for growth in those that do survive. This problem is on the agenda of public decision-makers in Spain, because, as we have pointed before, Spain is the country in the OECD with the second lowest survival rates of its SMEs. Moreover, firm growth does not have the same importance in all industrial sectors. The technology-based companies demonstrate a slightly differentiated behaviour. The official data places the survival rate of technologybased companies (TBC) at higher levels than for other companies. In addition, for the $\mathrm{TBC}$ that survive, the employment growth rate is clearly higher than in other sectors (Fariñas \& Huergo, 2015). This is why, in addition to small companies, we also focused on technology-based companies.

\section{Variables measurement}

\section{Dependent variable}

Employment growth: There is no consensus in the current literature on how to measure growth, and previous researchers have used several different measures. For example, growth of sales, employees, assets, profit, equity, and others have been used (Davidsson

\& Wiklund, 2000; Šarlija, Pfeifer, Jeger \& Bilandžić, 2016; Weinzimmer et al., 1998). In addition, qualitative features such as market position, quality of product, and customer 
goodwill have also been used. We choose employment growth because it is especially important in the context of small companies competing in sectors of medium high and high technology. As Davidsson et. al, $(2010$, p.6) pointed out: "high tech companies with rather long development times are not able to display any growth in sales or revenues for long periods of time. Yet, during this period they might still grow in terms of assetsincluding knowledge assets such as patents — and employment”.

In this work, we opted for relative variation in employment in the last three years as a measure of growth. In particular, we used information on the size of the current workforce (full-time workers) and the same indicator from three years ago. The variable used measures the relative rate of employment variation. It is a continuous variable that is expressed in percentages.

\section{Independent variables}

Family firm (FF): There is no single definition of a family firm, because it depends on the degree of family involvement. Consistent with previous researchers (e.g., GomezMejia et al. 2001; Gomez-Mejia et al. 2010) and considering the sample size, we established that a company is a family firm when the respondent confirms that there is a family member that directly or indirectly controls more than $50 \%$ of the company's shares, and at least one family member is on the board of the directors.

Family CEO (FCEO): A main focus in our work is to analyse whether the fact that the CEO belongs to the family or is an external professional has different effects on the company's growth. The academic literature indicates that family CEOs have generally been found to underperform compared to outside managers, both in terms of managerial capabilities (Bloom \& Van Reenen, 2007) and firm performance (Villalonga \& Amit, 
2006). In the survey, the respondent had to answer a question about this aspect. In our sample, 620 are family firms of which $55.1 \%$ are run by a family CEO.

Family Top Management Team (TMT): The presence of family members on the top management team, other than the CEO, is used in this paper as an indicator of the degree of family involvement in the company. There is a question in the survey related to this point. The variable FTMT takes the value of 1 if any member of the family belongs to the top management team, other than the CEO, and the value of 0 otherwise.

First generation: According to Gomez Mejia (2007), depending on which generation of the family the owner belongs, different importance is given to both economic and SEW goals. If we focus on CEOs who belong to the family, we can distinguish between family firms in which the CEO is the founder (first generation $=1$ ) and those where the CEO belongs to the second or subsequent generations; that is, the CEO is a descendant of the founder (first generation $=0$ ).

\section{Control variables}

To isolate the influence of family issues (CEO membership, family members in the top management and generation) on firm growth, we included several control variables. Following the integrative model of Wiklund et al. (2009) to explain firm growth, we propose three types of control variables: those related to human capital, the company, and the industry environment.

\section{Related to CEO}

CEO Education: What is the highest level of education that the CEO has achieved? This information was provided through an ordered variable ranging from 1 (the lowest) to 5 (the highest). 
CEO internal experience: This variable measures the number of years that the respondent was CEO of the current firm. One quarter of those interviewed spent less than five years as a company CEO, and only nine percent of them have worked as a CEO for 25 years or more.

\section{Related to the company}

Underfunded (UF): Whatever the ownership of the company, access to credit in order to have sufficient financing has been suggested (Cooper \& Gimeno-Gascon, 1992) to be a determinant of growth. The variable underfunded (UF) measures whether or not the availability of capital has represented a systematic disadvantage in the development of the company. The answer to a question regarding this issue is measured on a five-point Likert scale in which 1 means total disagreement with scarce financing and 5 total agreement.

Network: This variable seeks to capture the extent to which the company is immersed in a network of contacts. The variable is computed as the average of ten related questions given the importance of contacts with banks, clients, suppliers, employees, relatives, lawyers, adviser's office, and consultancy (up to a total of 10). Every item is answered on a five-point Likert scale. The Cronbach's alpha of the Network indicator is 0.72 .

Firm size (size): Due to economies of scale, firm size is a relevant factor that can affect firm growth. It was measured as the number of employees.

\section{Related to the industry environment}


Service-Industry (service): The importance of economies of scale in the industrial sector leads to the expected growth being different in the service sector than in the manufacturing industry. Service is a dichotomous variable that takes values 1 or 0 for service companies or manufacturing industry firms, respectively.

Technology change (Tech): The variable Tech measures the expectations of technological change in products or services. The variable is measured on a seven-point Likert scale, where the value 1 means that there are no changes, because the technology is well established; while 7 means very important technological changes and an evolving technology.

\subsection{Estimation method}

To analyse the effect of family involvement on the growth of the company, we estimated a general linear model where employment growth is the dependent variable. Hypothesis 1 was tested taking into account all of the valid individuals in the sample $(1,397$ family and non-family firms). However, Hypothesis 2 was tested only for family firms. Finally, Hypothesis 3 was tested only for family firms managed by a family member CEO (342 family CEO managed firms). Variance inflation factors indicate that our data are free of multicollinearity problems. All of the estimations have been carried out with robust standard errors, avoiding possible problems of heteroscedasticity.

In order to ensure robustness of our results, Hypothesis 1,2 and 3 were tested in a logit regression model where market share improvement is the dependent variable as a proxy of growth. The respondents were asked about the market share evolution over the last 3 years. The variable is coded as 1 when they have remained the same or increased market share or 0 when market share decreased. 


\section{Results}

Table 1 shows the structure of correlations of the variables as well as the mean and standard deviation of each variable in the whole sample and in each family of subsamples. Our sample is composed of $55.5 \%$ non-family companies; $24.5 \%$ are family businesses run by a family CEO and the remaining $20 \%$ are family firms managed by a professional CEO.

Employment variations are distributed around zero percent. The average value of the dependent variable, employment growth, is 0.025 , which indicates a very slight rate of employment growth in the stage under consideration. However, there are large differences that can be seen in the standard deviation. In family firms, only one out of four has experienced an increase in their workforce in the last three years. Among them, the employment growth average has been 0.48 . However, in non-family firms, one out of three of those have grown in employment, and the employment growth average is 0.63 .

A closer look at the correlation values shows significant correlations between independent variables and the dependent variable. It is important to note that all of the control variables have a significant correlation with the dependent variable, whether they are variables related to the CEO, the company, or the industrial environment.

The first column of Table 2 examines the results for Hypothesis 1. Taking the group of non-family companies as a reference, we observe that there are significant differences with respect to family businesses managed by a family member. Employment has declined in these companies if we compare it with non-family companies $(p=0.04)$. However, we do not find differences between family businesses managed by a non-family 
CEO and non-family businesses. This supports our Hypothesis 1, and it is in accordance with the analysis of other authors where family CEOs prefer to be cautious and less risky because they are aware of the possible negative consequences of losing family control over the firm (Casillas, Moreno \& Barbero, 2010). Therefore, although apparently firm growth has to be an important strategy for any CEO, family CEO priorities are different. Family CEOs avoid growing out of fear of losing control of the company. They opt for risk avoidance strategies to preserve their SEW (Allio, 2004).

As expected, the variables Underfunded (UF), firm size, age, network or service have a significant impact on employment variation. Managing a bigger firm with no difficulty in accessing resources and a wide net of contacts will lead to employment growth. The negative sign of the CEO internal experience variable may be explained by the fact that younger CEOs, with less internal experience, may have more pressure to grow while those with more experience intend to maintain their market shares in a sustained manner.

To test our Hypothesis 2, we only focus on family firms. The second column of Table 2 shows the results of the estimation.

In this model, we have three categories of interest. On one hand, we have to look at NFCEO-FTMT, which reports the presence of a non-family CEO and family TMT. The variable has a negative and significant sign with a high coefficient. This means that although it seems that non-family CEO involvement positively influences firm growth when family members are in TMT, this effect is negative in comparison with the category of reference which is family firms that are managed by non-family CEOs and with nonfamily TMT. It seems that for family firms, the best management leadership in terms of firm growth is to have professional CEOs and non-family members in the TMT. Thus, 
this result is consistent with previous findings advocating for the positive effects of clear leadership alignments (Miller et al., 2014). Therefore, by delving deeper into family firms managed by non-family CEOs, we have shown that the positive effect of these non-family CEOs in terms of growth is even higher when there is an alignment of interests between the CEO and the TMT. Some of the control variables have lost significance, but they all maintain their sign, which gives an idea of the robustness of the results.

On the other hand, we also have another category of interest in this model. This is FCEO, which reports the presence of a family CEO. This variable has a negative and significant sign. Thus, family firms with family CEOs, regardless of how the TMT is composed, have less growth than family firms with a professional CEO and non-family TMT.

It would be great to see differences between family-managed firms with family and nonfamily TMT, but our sample does not allow testing this. Due to the limitations of our sample, we only found four cases that are managed by a family CEO with non-family TMT and this cannot be representative of reality.

Thus, our Hypothesis 2 is confirmed. The results offer us a broader vision of the possibilities of leadership within a family business. Going deeper in the analysis of family firms, Hypothesis 2 offers us a different view. In fact, the real differences among nonfamily-managed firms came from the TMT composition. Among family firms, CEO identity is not enough to determine differences in growth. Adding the TMT composition, we are able to find that family firms will have higher growth when both the CEO and TMT are non-family members. According to the agency theory, if all of the members in the company have the same preferences, this translates into an improvement of results, which in this case is firm growth. 
A different aspect of family involvement is addressed in Hypothesis 3. Taking into account only those companies managed by family CEOs, we analysed the possible influence on growth of the CEO being the founder of the company as opposed to being the successor in second or later generations. The last column of Table 2 shows the results of the estimation. The variable generation with a positive sign and p-value of 0.002 confirms our hypothesis that if the CEO is the founder of a company, he or she has greater freedom of action and more authority over decisions than if he or she is a successor of the founder and there are other family members with different interests and varied visions of the company. Moreover, being the founder makes these CEOs more open to risky strategies, and since they are looking for new markets and trying to improve the efficiency of the company, they are more prone to risk. In addition, authority is totally centralized, so there are no agency problems. All of these characteristics lead to further employment growth.

Finally, we performed further robustness checks of our results which are shown in Table 3. In particular, we used another alternative measure of firm growth, market share. In this case, we used an alternative estimation technique, which is a logit regression model where market share improvement is the dependent variable. All of the results are robust to this different measure.

\section{INSERT TABLE 3 HERE}

If we jointly observe the six regressions from table 2 and 3 , we can see that the signs of the main control variables are maintained, which indicates the robustness of the models. The $U F$ (underfunded) variable always has a negative sign, as expected for companies with financing problems. The size and establishment of networks as well as the expectation of technological change have a positive influence on growth. With regard to 
the personal characteristics of the CEO, internal experience presents a negative and significant sign in the six regressions. This fact is particularly relevant in this context of high-tech companies. Managers who accumulate all of their experience in a single company and in the same sector do not guarantee faster growth. Such managers are more often members of family businesses.

Although the dependent variables in the two estimated models capture very different aspects of a company's growth, the results are consistent and robust. We can conclude that our sample endorses the three hypotheses raised.

\section{Conclusion}

In this study, we aim to show the effect of family involvement on employment growth. Therefore, illuminating differences in growth between family and non-family firms and among different types of family firms leads to a better understanding of growth in small high-tech firms.

The paper provides a better understanding of the type of companies with more flexible and less hierarchical structures: small companies in the high and medium-high technology sectors. As we have argued before, our sample of small firms is particularly suited to test our hypotheses given, among other things, the importance that owners' and CEOs' preferences have on strategic decision-making. But the sample of small firms is also important, because little evidence exists on the differences between family and nonfamily controlled firms in companies of this size.

The main contribution of this work is to highlight the relative advantages and the associated disadvantages of family involvement on firm growth in the context of Spanish small high-technology firms. 
Our research questions were formulated based on a theoretical framework including two perspectives, that is, the agency theory and the SEW perspective. This approach allowed us to contribute to the existing knowledge resulting from previous studies on family business growth.

We examined differences on growth in three types of firms, namely family-managed firms, non-family-managed but family-owned firms, and regular non-family firms. Moreover, we examined the crucial role of family involvement by considering the more nuanced effects of a family top management team and the generation of family control.

The heterogeneity observed in the growth of small family businesses indicates that this cannot simply be explained by ownership. It is necessary to delve deeper into the different responsibilities and levels of involvement that the family has in the firm. That is why this paper analyses the different graduations of family involvement, from CEO membership, through the management team membership, to the generation of the family CEO. Our work provides empirical support for theories suggesting that the growth of small businesses is conditional on the type of ownership and the management regime. (Hart, 2001). Therefore, in view of our results, an interesting question arises: which one of these two factors, management or ownership, is more important in determining firm growth? The results of our analysis have an impact on the fact that family businesses run by a nonfamily CEO present growth results similar to those of non-family companies and far above those with family CEOs. In other words, the difference in growth is associated with the CEO's membership in the family and not only with the ownership.

Regarding the first hypothesis, from the SEW perspective, we have shown that the preservation on socioemotional wealth could lead to lower employment growth. Familymanaged firms, where the CEO is part of the family, emphasize the "emotional" 
protection goals over pure economics. In this sense, they prefer to protect their firm by avoiding taking risky decisions that could affect their control over the firm. As family CEOs give more importance to non-economic goals, we have shown that family-managed firms, in comparison to the other two categories (non-family-managed family firms and non-family firms), are less likely to achieve growth. These arguments are in accordance with the negative effects of agency theory in family firms. After all, professional CEOs are chosen from a larger pool of talent. Family CEOs may retain the position as top manager because they enjoy being in charge and manage their lifework, the family firm, in their own way.

The second hypothesis suggests that the benefits of employing nonfamily CEOs is contingent on context. Our results show that non-family CEO effectiveness will be moderated if there are family members in the TMT. Families that hire an external CEO but keep some family member in the TMT do not give up the SEW perspective. They do not want to lose their control and their legacy. Moreover, the unity of the company could enter into crisis when agency problem arises, that is, when the non-family CEO has to share power with other family members.

Therefore, these findings demonstrate that there is still a long way to go in terms of heterogeneity among family firms. CEO membership is not enough to distinguish differences between family firms. We need to go deeper into the composition of the TMT. Relating to the generation stage of the firm, we have shown that among family firms, firm growth will be higher in first generation than in subsequent generation. This could be because when family ownership is divided among several members, the authority is diluted and decision-making loses effectiveness. Family members compete for their preferences (Schulze et al., 2003), particularly in the presence of diverse goals (Kotlar \& De Massis, 2013). Thus, compared to the second and subsequent generations, the first 
generation has greater power and legitimacy that makes the decision making process easier and faster, which leads to greater firm growth. In addition, family firms often become more risk averse after succession (Kaye and Hamilton, 2004). As next-generation family members are often more concerned for wealth preservation than further wealth creation, this can result in a lower orientation toward firm growth.

These results have been checked with two measures of firm growth: the variation in the number of employees and the evolution of the market share. There are many indicators that can approximate the polyhedral concept of firm growth. The employment growth must be understood as a growth in the inputs. The company that is successful or is developing new services and products is forced to increase its workforce. The improvements in the market share, on the other hand, should be interpreted as a measure of the growth in the outputs: a possible result of the increase in sales would be the presence in new markets or the improvement of the share in the markets in which we are already competing. Ultimately, this double measure leads us to ratify the importance of management in high-tech small businesses that have not only survived but have grown in two relevant dimensions.

\section{Practical Implications}

Our research also has some implications. Despite having analysed our research question in, a priori, a homogenous sample (small high-tech firms), having taken into account firm, individual, and industry control variables, the heterogeneity observed in the growth of small family businesses indicates that this cannot simply be explained by ownership. Thus, different combinations of family involvement were found to lead to different levels of firm growth. 
This paper has also some implications for management practice. According with the results, it seems that the factor which mostly matters in terms of growth is the management status and not only the ownership.

Family owners are surely very concerned with maintaining control of the company, because they believe that this is the best way to ensure that the firm will remain in the hands of their descendants. However, our work shows that if relevant positions are assigned to family members (CEO or TMT membership) in order to maintain control, that decision can slow down the growth of the company. Owners must explore other ways to maintain control of the company (for example through shareholders or the board of directors). If family owners hire family members to occupy managerial positions, perhaps they should establish requirements before assigning their relatives to positions of such responsibility. For example, they should demand certain training or educational level, managerial experience in other companies, or seniority in the company. If the family managers had similar characteristics to the externals (something that now does not happen since they have less training and no external management experience), it could be possible to avoid the negative effects of agency problems and they could preserve SEW values without harming the growth of the company.

Another suggestion could be to recommend that family owners encourage their successors to have the entrepreneurial spirit. New business leaders should not be so worried about the inherited wealth.

Our study highlights heterogeneity among growth in family firms. Based on the mixed evidence regarding the impact of family involvement on growth, scholars now should caution that comparing family and non-family firms' firm growth might be insufficient for attaining an understanding of how family ownership influences a firm's growth. 


\section{Limitations and future research}

This work presents some limitations. Firstly, the data is cross-sectional which does not allow researchers to infer causal relationships or effects over time. Secondly, our sample is limited to Spanish firms. Therefore, any generalization relative to other contexts should be done cautiously. Thirdly, we have used employment growth in this study and market share to test robustness, but we call on other researchers to explore the issues analysed here with other dependent variables.

Fourthly, one of our concerns was to detect which variables are associated with the survival and growth of Spanish companies with fewer than 50 workers in technologically advanced sectors. Due to the definition of the dependent variables (employment growth and market share evolution), our analysis focused on companies that have survived for at least 3 years. It would be very desirable to be able to carry out a similar study in order to analyse companies that do not survive and see if the presence of the family members in managerial positions has an influence on the survival of a company. Previous literature indicates that controlling families are more willing to accept lower performance and to resist short-term urges to sell or liquidate (DeTienne et al., 2013). This patient capital that is likely to sacrifice short-term performance to guarantee control and long-term survival of the firm is an asset of family firms as it allows the firm to navigate bad times for a longer period of time and therefore explore and exhaust all possible ways to recover (Capelleras, et al, 2020). In that sense, it would be curious to see if, in general, family businesses survive more or less.

Fifthly, although it is true that we do not measure the socioemotional wealth in the paper, we can see how it is implicitly present in family businesses. It would be very interesting to have a good indicator that measures the degree of importance of SEW in these companies and as a consequence see the influence of SEW on growth. 
Finally, a complementary way to measure the influence of the family would have been the percentage of ownership that the family has or the number of family members on the board of directors. However, neither of these two variables could be included in the model. Regarding the first one, this variable cannot be discriminatory because most of these small family businesses have more than $90 \%$ of the ownership in family hands. The second one could not be evaluated because small companies in the Spanish context do not have an obligation to have a formal board of directors.

In conclusion, our empirical results show that firms managed by family-CEOs have less firm growth in comparison with the other two groups. They also suggest that non-family CEOs provide higher growth when there is no family member in the TMT. Finally, we found that founder-led family firms have better firm growth than descendant-led family firms. 


\section{References}

Achtenhagen, L., Naldi, L., and Melin, L. 2010." "Business growth" — do practitioners and scholars really talk about the same thing?" Entrepreneurship Theory and Practice, 34(2): 289-316.

Alessandri, T. M., D. Cerrato and K. A. Eddleston, 2018, "The mixed gamble of internationalization in family and nonfamily firms: The moderating role of organizational slack”. Global Strategy Journal, 8: 46-72.

Allio, K.M. 2004. "Family businesses: Their virtues, vices, and strategic path". Strategy and Leadership, 32(4): 24-34.

Barringer, B. R., Jones, F. F., and Neubaum, D. O. 2005. “A quantitative content analysis of the characteristics of rapid growth firms and theirs founder". Journal of Business Venturing, 20(5): 663-687.

Barth, E., Gulbrandsen, T. and Schone, P. 2005. "Family ownership and productivity: the role of owner-management". Journal of Corporate Finance, 11: 107-127.

Bauweraerts, J., Diaz-Moriana, V., \& Arzubiaga, U. (2019). A Mixed Gamble Approach of the Impact of Family Management on Firm's Growth: A Longitudinal Analysis. European Management Review, https://doi.org/10.1111/emre.12359

Bennedsen, M, Kasper M. Nielsen, Pérez-Gonzalez, and Wolfenzon. 2007. "Inside the Family Firm: The Role of Families in Succession Decisions and Performance," Quarterly Journal of Economics, 122 (2):647-691, 
Berrone, P., Cruz, C., Gomez-Mejia, L. R., and Larraza-Kintana, M. 2010. "Socioemotional wealth and organizational response to institutional pressures: Do family controlled firms pollute less?” Administrative Science Quarterly, 55: 82-113.

Bertrand, M., and Schoar, A. 2006. "The role of family in family firms". Journal of Economic Perspectives, 20: 73-96.

Bloom, N. and Van Reenen, J. 2007. "Measuring and Explaining Management Practices Across Firms and Countries”. NBER Working Paper No. 12216.

Brush, C. G., Ceru, D. J., and Blackburn, R. 2009. "Pathways to entrepreneurial growth: the influence of management, marketing, and money". Business Horizons, 52(5): 481491

Cannella, A., Jones, C., and Withers, M. 2014. "Family-versus lone-founder-controlled public corporations: Social identity theory and boards of directors". Academy of Management Journal, 58: 436-459.

Cannella, A.A., Jones, C.D., \& Withers, M. 2015. "Family-versus lone-founder controlled public corporations: Social identity theory and board of directors". Academy of Management Journal, 58 (2): 436-459.

Capelleras, J.L. Contin-Pilart, I, Garcés-Galdeano, L and Larraza-Kintana, M. 2020. “The role of entrepreneurial orientation and family control of the firm in the economic recovery of underperforming firms" Academia, Revista Latinoamericana de Administración, Forthcoming.

Carney, M. 2005. “Corporate governance and competitive advantage in family-controlled firms". Entrepreneurship Theory and Practice, 29(3): 249-265. 
Casillas, J. C., Moreno, A. M., and Barbero, J. L. 2010. “A configurational approach of the relationship between entrepreneurial orientation and growth of family firms". Family Business Review, 23(1): 27-44.

Chandler, A.D. Jr. 1990. "Scale and Scope: The Dynamics of Industrial Capitalism". Cambridge, MA: Harvard University Press.

Chrisman, J.J., Chua, J.H., and Steier, L. 2003. "Editorial: An introduction to theories of family business". Journal of Business Venturing, 18(4): 441-448.

Chrisman, J. J., Fang, H., Kotlar, J., and De Massis, A. 2015. “A note on family influence and the adoption of discontinuous technologies in family firms". Journal of Product Innovation Management, 32(3): 384-388.

Chua, J. H., Chrisman, J. J., and De Massis, A. 2015. “A closer look at socioemotional wealth: its flows, stocks, and prospects for moving forward". Entrepreneurship Theory and Practice, 39(2): 173-182.

Connelly, B., Hoskisson, R., Tihanyi, L., \& Trevis Certo, S. 2010. “Ownership as a form of corporate goverance”. Journal of Management Studies, 47(8): 1561-1589.

Cooper, A., Gimeno-Gascon, F. J. 1992. "Entrepreneurs, processes of founding, and new firm performance', in Sexton, D., Kasarda, J., eds, The State of the Art in Entrepreneurship, PWS Kent Publishing Co, Boston, MA, 301-324.

Cruz, C. , Gomez-Mejia, L. R., and Becerra, M. 2010. "Perceptions of benevolence and the design of agency contracts: CEOS-TMT relationships in family firms". Academy of Management Journal, 53(1): 69-89.

Cruz, C., and Nordqvist, M. 2012. "Entrepreneurial orientation in family firms: A generational perspective". Small Business Economics, 38(1): 33-49 
Cruz. C., Larraza-Kintana M., Garcés-Galdeano L., and Berrone P. 2014. “Are family firms really more socially responsible?". Entrepreneurship Theory and Practice, 38(6):1295-1316.

Cycyota, C. S., and Harrison, D. A. 2002. "Enhancing Survey Response Rates at the Executive Level: Are Employee- or Consumer-Level Techniques Effective?” Journal of Management, 28(2): 151-176.

Daily, C. M., and Thompson, S. S. 1994. "Ownership structure, strategic posture, and firm growth: An empirical examination”. Family Business Review, 7(3): 237-249.

Davidsson, P., and J. Wiklund, 2000. "Conceptual and empirical challenges in the study of firm growth", In Sexton, D. and H. Landström, (Eds.), The Blackwell Handbook of Entrepreneurship. Oxford, MA: Blackwell Business

Davidsson, P., Achtenhagen, L., and Naldi, L. 2010. "Small firm growth". Foundations and Trends in Entrepreneurship, 6(2): 69-166.

Davis, A. E., and Shaver, K. G. 2012. "Understanding Gendered variations in business growth intentions across the life course". Entrepreneurship Theory and Practice, 36(3): 495-512.

De Massis, A., Kotlar, J., Chua, J. H., \& Chrisman, J. J. 2014. “Ability and willingness as sufficiency conditions for family-oriented particularistic behavior: implications for theory and empirical studies". Journal of Small Business Management, 52(2): 344-364.

De Massis A., Frattini F., Pizzurno E., Cassia L. 2015. "Product Innovation in Family versus Non-Family Firms: an Exploratory Analysis". Journal of Small Business Management, 53(1): 1-36. 
DeTienne, D.R. and Chirico, F., 2013. "Exit strategies in family firms: how socioemotional wealth drives the threshold of performance". Entrepreneurship Theory and Practice. 37 (6): 1297-1318.

Doern, R. 2009. “Investigating barriers to SME growth and development in transition environment": a critique and suggestions for developing the methodology". International Small Business Journal, 27(3): 275-305.

European Commission, 2002. Corporate Social Responsibility: A business contribution to sustainable development. COM (2002). 347

Fariñas, J. C.; Huergo, E. (2015). “Demografía empresarial en España: tendencias y regularidades". FEDEA: Studies on the Spanish Economy.

Finkelstein, S. 1992. "Power in top management teams: dimensions, measurement and validation". Academy of Management Journal, 35: 505-538.

Garcés-Galdeano, L. and García-Olaverri, C. (2019), "The hidden value of intangibles: do CEO characteristics matter?", International Journal of Manpower, 40 (6): 1075-1091.

Garcés-Galdeano, L. Larraza-Kintana,M., Cruz, C. and Contín-Pilart, I. 2017. "Just about money? CEO satisfaction and firm performance in small family firms". Small Business Economics, 49 (4): 825-839.

Garcés-Galdeano, L. Larraza-Kintana, M. García-Olaverri, C. and Makri, M. 2016. "Entrepreneurial orientation in family firms: the moderating role of technological intensity and performance". International Entrepreneurship and Management Journal, $12(1): 27-45$ 
Giovannoni E., Maraghini M.P., Riccaboni A. (2011). “Transmitting Knowledge Across Generations: The Role of Management Accounting Practices”, Family Business Review, 24(2):126-150.

Gomez-Mejia, L. R., Haynes, K. T., Núñez-Nickel, M., Jacobson, K. J. L., and MoyanoFuentes, J. 2007. "Socioemotional wealth and business risks in family-controlled firms: Evidence from Spanish olive oil mills". Administrative Science Quarterly, 52(1): 106137.

Gomez-Mejia, L. R., Nuñez-Nickel, M., and Gutierrez, I. 2001. "The role of family ties in agency contracts". Academy of Management Journal, 44(1): 81-95.

Gómez-Mejía, L.R., Tochman Campbell, J., Martin, G., Hoskisson, R.E., Makri, M. \& Sirmon, D.G. (2013) Socioemotional wealth as a mixed gamble: revisiting family firm R\&D investments with the behavioral agency model. Entrepreneurship Theory and Practice, 38 (6): 1351-1374.

Gómez-Mejía, L., C. Cruz and C. Imperatore, 2014. "Financial reporting and the protection of socioemotional wealth in family-controlled firms". The European Accounting Review, 23: 387-402.

Grassby, R. 2000. “Kinship and Capitalism”. Cambridge, MA: Cambridge University Press.

Gupta, P. D., Guha, S., and Krishnaswami, S. S. 2013. "Firm growth and its determinants". Journal of Innovation and Entrepreneurship, 2(1): 1-14.

Hambrick, D. and Mason, P. 1984. "Upper echelons: the organization as a reflection of its top managers". Academy of Management Review, 9(2): 193-206. 
Hambrick, D. (2007). Upper Echelons Theory: An Update. Academy of Management Review, 32(2): 334-343.

Hamelin, A. 2013. "Influence of family ownership on small business growth. Evidence from French SMEs”. Small Business Economics, 41: 563-579.

Hart, O. 2001. "Financial contracting". Journal of Economic Literature, 39(4): 10791100.

Hauswald, H., Hack, A., Kellermanns, F. W., and Patzelt, H. 2015. “Attracting new talent to family firms: Who is attracted and under what conditions?" Entrepreneurship Theory and Practice, 40(5): 963-989.

Huerta E. y Salas, V. (2012): «La calidad del Recurso empresarial en España: Indicios e implicaciones para la competitividad» Papeles de Economía Española, 132: 19-36.

Huybrechts, J., Voordeckers, W. and Lybaert, N. (2013) 'Entrepreneurial risk taking of private firms: the influence of a nonfamily CEO and the moderating effect of CEO Tenure', Family Business Review, Vol. 26, No. 2, pp.161-179.

Jansen, J. J. P., Van den Bosch, F. A. J., and Volberda, H. W. 2006. "Exploratory innovation, exploitative innovation, and performance: Effects of organizational antecedents and environmental moderators”. Management Science, 52: 1661-1674.

Jehn, K.A. (1997). “A quantitative analysis of conflict types and dimensions in organizational groups”. Administrative Science Quarterly, 42(3): 530-558.

Kellermanns, F.W. and Eddleston, K.A. 2004. "Feuding families: when conflict does a family firm good". Entrepreneurship Theory and Practice, 28(3): 209-228.

Kellermanns, F.W. and Eddleston, K.A. 2007. "A family perspective on when conflict benefits family firm performance". Journal of Business Research, 60(10): 1048-1057. 
Klein, S. B., Astrachan, J. H. and Smyrnios, K. X. 2005. "The F-PEC Scale of Family Influence: Construction, Validation, and Further Implication for Theory". Entrepreneurship Theory and Practice, 29: 321-339.

Kotlar, J., and De Massis, A. 2013. "Goal setting in family firms: Goal diversity, social interactions, and collective commitment to family-centered goals". Entrepreneurship Theory and Practice, 37(6): 1263-1288.

Mahto, R. V., Davis, P. S., Pearce II, J. A., and Robinson Jr., R. B. 2010. "Satisfaction with firm performance in family business". Entrepreneurship Theory \& Practice Journal, 34(5), 985-1001.

Miller, D., and Le Breton-Miller, I. 2014. "Deconstructing Socioemotional Wealth". Entrepreneurship Theory and Practice, 38(4): 713-720.

Miller, D., Le Breton-Millier, I. and Scholnick, B. 2008. "Stewardship vs stagnation: An empirical comparison of small family and non-family businesses". Journal of Management Studies, 45(1): 51-78.

Miller, D., Minichilli, A., and Corbetta, G. 2013. "Is family leadership always beneficial?" Strategic Management Journal, 34(5): 553-571.

Miller, E.J. and Rice, A.K. 1988. "The family business in contemporary society”. Family Business Review, 1: 193-210.

Mitchell, J.R., Hart, T.A., Valcea, S. and Townsend, D.M. 2009. "Becoming the boss: Discretion postsuccession success in family firms". Entrepreneurship, Theory Practice, 33(6): 1201-1218.

Nordqvist, N., Habbershon, T.G. and Melin, L. 2008. "Trangenerational entrepreneurship: exploring EO in family firms". In Landstrom, H., Crijins, H. and Laveren, E. (Eds). 
Entrepreneurship, Sustainable Growth and performance: Frontiers in European Entrepreneurship Research (pp.93-116). Cheltenham: Edward Elgar.

OECD, 2016 Entrepreneurship at a glance, OECD Publishing,

Pérez-González, F. (2006). "Inherited Control and Firm Performance." American Economic Review , 96, 1559-1588.

Pittino, D., Chirico, F., Henssen, B., \& Broekaert, W. (2019). Does increased generational involvement foster business growth? The moderating roles of family involvement in ownership and management. European Management Review, https://doi.org/10.1111/emre.12366

Podsakoff, P.M., MacKenzie, S.B., Lee, J.Y. and Podsakoff, N.P. 2003. "Common method biases in behavioral research: a critical review of the literature and recommended remedies”, Journal of Applied Psychology, Vol. 88 No. 5, pp. 879-903

Rauch, A. and Rijskik, S.A. 2013. "The effects of general and specific human capital on long-term growth and failure of newly founded businesses". Entrepreneurship Theory and Practice, (3): 923-941.

Saridakis, G, Lai, Y., Muñoz Torres, R. Mohammed, A.M., (2018) "Actual and intended growth in family firms and non-family-owned firms: are they different?", Journal of Organizational Effectiveness: People and Performance, (5):1, 2-21.

Šarlija, N., Pfeifer, S., Jeger, M., Bilandžić A. 2016. "Measuring Enterprise Growth: Pitfalls and Implications”, International Scholarly and Scientific Research \& Innovation, 10(6): 1606-1613

Schulze, W.S., Lubatkin, M.H. and Din, R.N. 2003. "Toward a theory of agency and altruism in family firms". Journal of Business Venturing, 18: 473-490. 
Stenholm, P., Pukkinen, T., and Heinonen, J. 2016. "Firm Growth in Family BusinessesThe Role of Entrepreneurial Orientation and the Entrepreneurial Activity". Journal of Small Business Management, 54(2): 697-713.

Tsai, W.-H., Kuo, Y.-C., and Hung, J.-H. 2009. "Corporate diversification and CEO turnover in family businesses: Self-entrenchment or risk reduction?" Small Business Economics, 32: 57-76.

Villalonga, B. and Amit, V. .2006. "How do family ownership, control and management

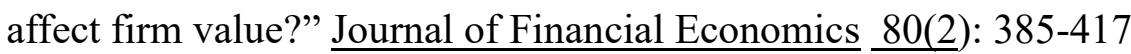

Ward, J. L. 1997. "Growing the family business: Special challenges and best practices". Family Business Review, 10(4): 323-337.

Wennberg, K., Wiklund, J., Hellerstedt, K. and Nordqvist, M. 2011. "Implications of Intra-Family and External Ownership Transfer of Family Firms: Short-Term and LongTerm Performance Differences". Strategic entrepreneurship Journal, 4(5): 352-372.

Wiklund, J., Davdisson, P. and Delmar, F. 2003. "What do they think and feel about growth? An expectancy-value approach to small business managers' attitudes towards growth”. Entrepreneurship Theory and practice, Spring, 247-270.

Wiklund, J., Patzelt, H., and Shepherd, D. A. 2009. "Building an integrative model of small business growth”. Small Business Economics, 32(4): 351-374.

Wright, M., and Stigliani, I. 2012. “Entrepreneurship and growth”. International Small Business Journal, 31(1): 3-22.

Zellweger, T., Nason, R., Nordqvist, M., and Brush, C. 2013. "Why do family firms strive for nonfinancial goals? An organizational identity perspective". Entrepreneurship Theory and Practice, 37(2): 229-248. 
Figure 1: It shows the sequence followed by hypothesis.

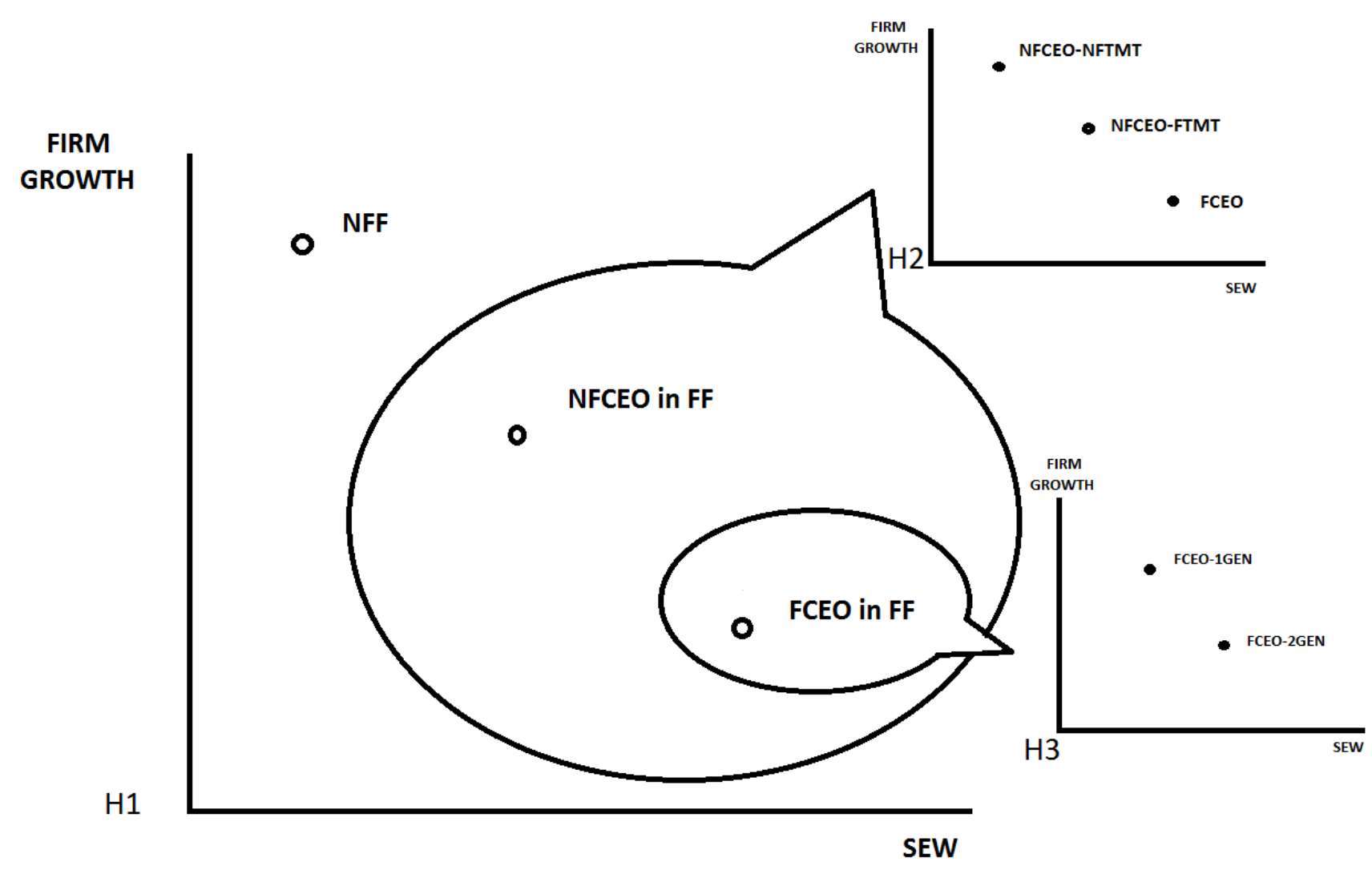


TABLE 1: Descriptive Statistics and Correlation Coefficients.

\begin{tabular}{|c|c|c|c|c|c|c|c|c|c|c|c|}
\hline \multicolumn{8}{|c|}{$\begin{array}{c}\text { CORRELATION MATRIX } \\
\text { WHOLE Sample } \\
\text { N = } 1397\end{array}$} & \multirow{2}{*}{$\begin{array}{l}\text { Whole } \\
\text { Sample } \\
N=1397 \\
\text { Mean (sd) }\end{array}$} & \multirow{2}{*}{$\begin{array}{l}\text { FF } \\
\text { Subsample } \\
N=620 \\
\text { Mean (sd) }\end{array}$} & \multirow{2}{*}{$\begin{array}{l}\text { Family CEO in } \\
\text { FF Subsample } \\
\mathrm{N}=342 \\
\\
\text { Mean (sd) }\end{array}$} & \multirow{2}{*}{$\begin{array}{l}\text { First } \\
\text { Generation- } \\
\text { Family CEO in } \\
\text { FF Subsample } \\
\mathrm{N}=187 \\
\text { Mean (sd) }\end{array}$} \\
\hline & 1 & 2 & 3 & 4 & 5 & 6 & 7 & & & & \\
\hline 1. Growth & 1 & & & & & & & $0.025(0.6)$ & $-0.026(0.5)$ & $-0.080(0.4)$ & $-0.050(0.5)$ \\
\hline 2. CEO Education & $0.11^{*}$ & 1 & & & & & & $3.24 \quad(1.1)$ & $3.06 \quad(0.8)$ & $2.87(0.9)$ & $2.64(1.0)$ \\
\hline $\begin{array}{l}\text { 3. CEO Internal } \\
\text { Experience }\end{array}$ & $-0.14^{*}$ & $-0.33^{*}$ & 1 & & & & & 12.1 & $13.43(9.3)$ & $15.7(9.4)$ & $18.58(9.5)$ \\
\hline 4. UF & $-0.10 *$ & -0.03 & -0.01 & 1 & & & & $2.89(1.5)$ & $2.91(1.5)$ & $3(1.5)$ & $3.03(1.5)$ \\
\hline 5. NETWORK & $0.06^{*}$ & -0.00 & $-0.06^{*}$ & $0.06^{*}$ & 1 & & & $2.74 \quad(0.6)$ & $2.78(0.6)$ & $\begin{array}{ll}2.85 & (0.7) \\
\end{array}$ & $2.82(0.7)$ \\
\hline 6. SIZE & $0.13^{*}$ & $0.20 *$ & -0.05 & $-0.10 *$ & 0.02 & 1 & & $21.07(13.1)$ & $22.0(13.1)$ & $20.45(12.3)$ & $19.67(11.9)$ \\
\hline 7. SERVICE & $0.18^{*}$ & $0.19 *$ & $-0.19 *$ & -0.03 & 0.02 & 0.04 & 1 & $0.29 \quad(0.4)$ & $0.20(0.3)$ & $0.15(0.3)$ & $0.21(0.4)$ \\
\hline 8. TECH & $0.10^{*}$ & $0.13^{*}$ & -0.05 & -0.00 & 0.04 & 0.05 & $0.21^{*}$ & $3.32 \quad(2.1)$ & 3.22 (1.9) & $3.24(2.0)$ & $3.28(2.0)$ \\
\hline
\end{tabular}

* Significant at $p<.05$ 
Table 2: OLS Regression Analysis

\begin{tabular}{|c|c|c|c|c|c|c|}
\hline & H1 & & $\mathrm{H} 2$ & & H3 & \\
\hline & Growth & & Growth & & Growth & \\
\hline FCEO_FF & -0.067 & $*$ & -0.289 & $* * *$ & & \\
\hline NFCEO_FF & -0.043 & & & & & \\
\hline NFCEO-FTMT & & & -0.302 & $* * *$ & & \\
\hline First Generation & & & & & 0.152 & $* *$ \\
\hline Size & 0.007 & $* * *$ & 0.006 & $* * *$ & 0.010 & $* * *$ \\
\hline CEO Education & 0.003 & & -0.012 & & -0.012 & \\
\hline CEO internal experience & -0.003 & $* * *$ & -0.003 & $* *$ & -0.004 & $* *$ \\
\hline UF & -0.035 & $* * *$ & -0.039 & $* *$ & -0.044 & $*$ \\
\hline Tech & 0.007 & $*$ & 0.028 & $* *$ & 0.021 & + \\
\hline Network & 0.013 & & 0.031 & & 0.037 & \\
\hline Service & 0.133 & $* * *$ & 0.076 & & -0.054 & \\
\hline N.obs. & 1397 & & 620 & & 342 & \\
\hline $\mathbf{F}$ & 19.58 & $* * *$ & 8.383 & $* * *$ & 7.278 & $* * *$ \\
\hline R.Squared & 0.133 & & 0.110 & & 0.149 & \\
\hline
\end{tabular}

Significance levels are based on a two-tailed test $+: p<0.1 ; *^{*}: p<0.05 ;{ }^{* *}: p<0.01 ;{ }^{* * *}: p<0.001$.

H1: Sample: Family and non-family firms. Reference group: non-family firms

H2: Sample: Only Family firms. Reference group: Family firms with non-family CEO and nonfamily TMT

H3: Sample: Family CEO firms. Reference group: descendant-led family firms 
Table 3: Robustness check: Logit Regression Analysis

\begin{tabular}{|c|c|c|c|c|c|c|}
\hline \multirow[b]{3}{*}{ FCEO_FF } & \multicolumn{2}{|l|}{ H1 } & \multicolumn{2}{|l|}{$\mathrm{H} 2$} & \multicolumn{2}{|l|}{ H3 } \\
\hline & \multicolumn{2}{|c|}{ Market Share } & \multicolumn{2}{|c|}{ Market Share } & \multicolumn{2}{|c|}{ Market Share } \\
\hline & -0.263 & + & -0.660 & + & & \\
\hline NF CEO_FF & -0.180 & & & & & \\
\hline NFCEO-FTMT & & & -0.706 & + & & \\
\hline First Generation & & & & & 0.559 & $* *$ \\
\hline Size & 0.035 & $* * *$ & 0.064 & $* * *$ & 0.075 & $* * *$ \\
\hline CEO Education & 0.076 & & -0.062 & & -0.048 & \\
\hline CEO internal experience & -0.005 & & -0.013 & $* *$ & -0.034 & $* *$ \\
\hline UF & -0.210 & $* * *$ & -0.372 & $* *$ & -0.481 & $* * *$ \\
\hline Tech & 0.054 & + & 0.068 & $* *$ & 0.013 & \\
\hline Network & 0.078 & & 0.222 & & 0.539 & $* *$ \\
\hline Service & 0.591 & $* * *$ & 0.812 & $* * *$ & 0.787 & + \\
\hline N.obs. & 1352 & & 597 & & 327 & \\
\hline Log likelihood & 1548,476 & $* * *$ & 618,957 & $* * *$ & 336,991 & $* * *$ \\
\hline R.Squared & 0.123 & & 0.251 & & 0.311 & \\
\hline
\end{tabular}

Significance levels are based on a two-tailed test $+: \mathrm{p}<0.1 ; *: \mathrm{p}<0.05 ; * *: \mathrm{p}<0.01 ; * * *: \mathrm{p}<0.001$. 
